\title{
Effects of Fertilization on a Mixed Stand of Cheatgrass and Intermediate Wheatgrass
}

\section{BURGESS L. KAY AND RAYMOND A. EVANS}

Associate Specialist, Department of Agronomy, University of California, Davis, California; and Research Range Conservationist, Crops Research Division, Agricultural Research Service, USDA, University of Nevada, Reno, Nevada.

\section{Highlight}

Applied nitrogen increased competition between cheatgrass and intermediate wheatgrass for soil moisture and resulted in death of wheatgrass. Grazing further increased this effect. Forage increases occurred in two of four years but did not justify cost.

Fertilization of seeded perennial grasses in sagebrush areas of the West is mostly experimental. Previous studies by Eckert et al. (1961), Kilcher (1958), and Sneva et al. (1958) indicate fertilizers will increase yield and quality of forage in areas having an average precipitation of 10 inches or more. Kay et al. (1957, 1958) reported yield increases of annuals, particularly cheatgrass (Bromus tectorum L.), in response to nitrogen application. Such increased growth of annual species would offer greater competition to seeded perennial grasses.

The study presented here was established: (1) to determine the responses of a mixed stand of intermediate wheatgrass ( $A g$ ropyron intermedium (Host) Beauv.) and cheatgrass to various rates and combinations of fertilizers; (2) to ascertain the competitive effects of each species under various fertility regimes; (3) to determine the effects of environmental factors, especially precipitation, on responses of both species to fertilizer, and (4) to determine the practicability of fertilizing established stands of intermediate wheatgrass and cheatgrass under semi-arid conditions.

\section{Methods}

The study was conducted on the University of California Demonstration Range, 2 miles northeast of the town of Likely in the extreme northeast corner of the state 1 . The area is commonly referred to as tableland, and usually grows big sagebrush (Artemisia tridentata Nutt.), cheatgrass, squirrel tail (Sitanion hystrix (Nutt.) J. G. Smith), Sandberg bluegrass (Poa secunda Presl), and red-stem filaree (Erodium cicutarium (L.) L'Her.). Annual precipitation averages 10 inches, with seasonal totals varying widely. The elevation is 4,500 feet, and the growing season is short and variable. Cheatgrass may germinate as early as October or as late as March, but seldom is tall enough to graze before May. In a warm wet season, growth may start as

1 The cooperation of rancher Warren Fluornoy on whose land this study was conducted is gratefully acknowledged. early as February. The annual grass matures about the first week of June and is dry by the end of June. Winter temperatures commonly fall below zero; summer temperatures may exceed $100^{\circ} \mathrm{F}$. The soil is gravelly loam over clay superimposed over a cemented layer on basaltic bedrock (Yancy series). Total soil depth averages 10 to 20 inches. Livestock use generally is from April 15 to June 15.

Two adjacent fertilizer trials were established in the fall of 1958 on a 1-year-old seeding of Greenar intermediate wheatgrass. One trial was fenced to exclude cattle, deer, antelope, and rabbits; and the small rodents were poisoned as recommended by Howard et al. (1957). The second trial was identical in design, but left open to grazing by all animals. Nine fertilizer treatments were replicated four times in each trial in a randomized block design. Nitrogen was applied as ammonium nitrate at rates of 30,60 , or $120 \mathrm{lb}$ actual nitrogen per acre. Each of these nitrogen rates also was applied in combination with $40 \mathrm{lb} / \mathrm{A}$ sulfur applied as gypsum. The remaining treatments were $40 \mathrm{lb} / \mathrm{A}$ sulfur alone, $60 \mathrm{lb} / \mathrm{A}$ nitrogen as ammonium sulphate, and an unfertilized check plot. Each treatment plot was $15 \times 15 \mathrm{ft}$. All nitrogen (N) and nitrogen plus sulfur (NS) treatments in the fenced trial were split in half at the end of the first growing season (1959) and the nitrogen application repeated on one-half (R). This same half of the plotreceived a third application of nitrogen at the end of the second growing season (1960). The re- 
maining half received only the initial application of nitrogen. Sulfur application was not repeated.

Yield data were taken on fenced plots only. The entire plot area was harvested to a 2-inch stubble height, using a rotary lawn mower with bag attachment. Original plans included harvesting periodically during the growing season to simulate grazing, with the number of clipping depending on the amount of growth produced and length of growing season. Because of the low-rainfall years encountered, the actual numbers of clippings were none in 1959, two in 1960 , and one each in 1961 and 1962.

Botanical composition in terms of percent ground cover was determined by the step-point method described by Evans and Love (1957) in both the fenced and unfenced plots. Thirty points and five squarefoot cover estimates were taken per plot (a total of 120 points and 20 cover estimates per treatment) each year.

\section{Results and Discussion}

Precipitation during the 4 years of this study was considerably below normal -4.92 inches in 1958-59; 7.28 inches in 1959-60; 5.37 inches in 1960-61, and 9.75 inches in 1961-62. In addition to the extremely low total rainfall in 1958-59 and 1960-61 there was an almost complete lack of rain during the spring months in those same years - the period when nearly all plant growth normally occurs. The drought was reflected in the differential responses of the species as well as in total herbage yield.

\section{Effects on Ground Cover}

Fenced plot.-The first year after treatment (1959), ground cover of cheatgrass was increased over four times by the high nutrient treatment (from 5\% to $21 \%$ ). Ground cover of wheatgrass was doubled by the same treatment (from 6\% to 12\%), while total ground cover tripled (from $13 \%$ to $38 \%$ ). Earlier

Table 1. Effects of fertilizer on percent ground cover-fenced plots.

\begin{tabular}{|c|c|c|c|c|c|c|c|c|c|}
\hline \multirow[b]{2}{*}{ Treatment ${ }^{1}$} & \multicolumn{3}{|c|}{1960} & \multicolumn{3}{|c|}{1961} & \multicolumn{3}{|c|}{1962} \\
\hline & $\begin{array}{l}\text { Cheat- } \\
\text { grass }\end{array}$ & $\begin{array}{l}\text { Wheat- } \\
\text { grass }\end{array}$ & Total & $\begin{array}{c}\text { Cheat- } \\
\text { grass }\end{array}$ & $\begin{array}{l}\text { Wheat- } \\
\text { grass }\end{array}$ & Total & $\begin{array}{c}\text { Cheat- } \\
\text { grass }\end{array}$ & $\begin{array}{l}\text { Wheat- } \\
\text { grass }\end{array}$ & Total \\
\hline None (check) & 10.0 & 3.0 & 13.0 & 2.0 & 3.8 & 6.0 & 5.3 & 22.8 & 30.0 \\
\hline $\mathrm{N}_{30}$ & 15.5 & 4.8 & 22.8 & 6.3 & 3.7 & 10.0 & 24.5 & 16.3 & 42.5 \\
\hline $\mathrm{N}_{30} \mathrm{R}$ & 17.8 & 7.3 & 25.3 & 4.5 & 4.8 & 9.8 & 32.5 & 15.8 & 52.5 \\
\hline $\mathrm{N}_{60}$ & 23.8 & 4.0 & 28.0 & 9.0 & 4.0 & 13.0 & 30.5 & 13.8 & 47.5 \\
\hline $\mathrm{N}_{60} \mathrm{R}$ & 27.8 & 5.0 & 33.3 & 6.3 & 3.0 & 10.0 & 54.0 & 13.0 & 67.5 \\
\hline $\mathrm{N}_{120}$ & 27.8 & 4.5 & 33.8 & 9.0 & 1.8 & 11.0 & 49.0 & 14.0 & 70.0 \\
\hline$N_{120} R$ & 29.0 & 3.5 & 34.0 & 5.0 & 1.8 & 7.0 & 54.3 & 6.0 & 67.5 \\
\hline $\mathrm{S}_{40}$ & 10.0 & 6.0 & 16.0 & 3.0 & 5.3 & 8.3 & 7.0 & 22.0 & 30.0 \\
\hline AS-300 & 25.8 & 5.0 & 31.3 & 11.5 & 4.3 & 15.8 & 40.5 & 15.8 & 57.5 \\
\hline AS-300R & 31.3 & 5.0 & 36.5 & 6.5 & 4.5 & 11.0 & 65.3 & 7.3 & 77.5 \\
\hline $\mathrm{N}_{30} \mathrm{~S}_{40}$ & 16.5 & 4.0 & 20.8 & 5.5 & 4.0 & 9.8 & 16.3 & 17.5 & 35.0 \\
\hline $\mathrm{N}_{30} \mathrm{~S}_{40} \mathrm{R}$ & 20.5 & 4.8 & 25.5 & 7.3 & 5.3 & 12.8 & 27.8 & 13.5 & 42.5 \\
\hline $\mathrm{N}_{60} \mathrm{~S}_{40}$ & 23.8 & 3.5 & 28.3 & 12.5 & 3.3 & 16.0 & 30.3 & 16.8 & 52.5 \\
\hline $\mathrm{N}_{60} \mathrm{~S}_{40} \mathrm{R}$ & 23.5 & 4.8 & 39.8 & 8.3 & 1.8 & 10.5 & 52.8 & 5.3 & 65.0 \\
\hline $\mathrm{N}_{120} \mathrm{~S}_{40}$ & 32.5 & 3.8 & 37.0 & 7.0 & 1.5 & 8.8 & 54.8 & 6.0 & 65.0 \\
\hline $\mathrm{N}_{120} \mathrm{~S}_{40} \mathrm{R}$ & 34.3 & 4.5 & 41.5 & 4.3 & 1.7 & 6.0 & 71.8 & 6.5 & 85.0 \\
\hline LSD .05 & 8.2 & NS & 8.3 & 4.8 & 2.0 & 4.6 & 16.3 & 8.6 & 13.4 \\
\hline .01 & 11.0 & - & 11.0 & 6.5 & 2.7 & 6.1 & 21.7 & 11.5 & 17.9 \\
\hline
\end{tabular}

1 Rates of nitrogen (N) and sulfur (S) are given in lb/A, R refers to annual reapplication of nitrogen. AS refers to ammonium sulfate and $\mathrm{lb} / \mathrm{A}$ of this material.

growth of cheatgrass was noted on the $\mathrm{N}$ plots than on the check plots.

The ground cover of wheatgrass was reduced considerably in all plots the second year, 1960 (Table 1). This probably was the result of the extremely low rainfall the previous year. Cheatgrass increased proportionately, and total ground cover remained unchanged even though total precipitation was increased considerably over the preceding year.

Total ground cover on all plots was considerably lower the third year (1961) than the second as the result of another dry year. Wheatgrass showed a slight increase on the check, probably the result of the improved rainfall the previous year. However, fertilized wheatgrass continued to decline in ground cover, apparently because of the mortality suffered in this series of dry seasons, combined with the competitive effects of an increased amount of cheatgrass resulting from fertilizer treatments. Cheatgrass was much less on all plots in the third year than the second.
The fourth year (1962) had about average rainfall, but was unusually productive because much of the rain fell during the spring growing period. Ground cover was increased considerably for both species over the third year on both the checks and on the fertilized plots. However, the fertilized plots again produced an excessive amount of cheatgrass; and, although wheatgrass was able to recover somewhat from the previous year, the amount of recovery was considerably less than that on the unfertilized checks.

Grazed plot.-The plots were not grazed except by wildlife in 1959 because of an almost complete lack of forage production. Grazing in 1960 did not affect total ground cover or ground cover of cheatgrass of either the check or the $\mathrm{N}_{120} \mathrm{~S}_{40}$ plot, but wheatgrass on the check was decreased to $1.3 \%$ by grazing compared with $3.0 \%$ on the fenced check. The grazed-fertilized wheatgrass also was reduced more than the fenced and fertilized wheatgrass (reduced to $0.5 \%$ compared to $3.8 \%$ ) . 


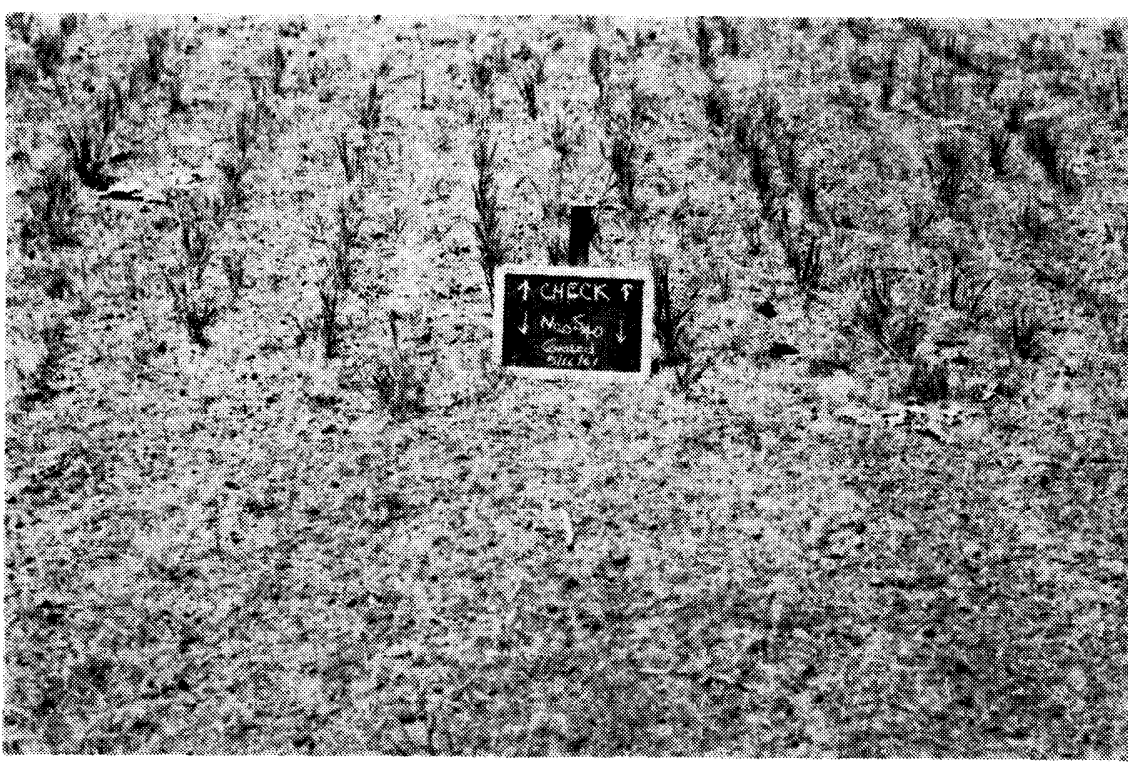

Figure 1. Grazed study- $\mathrm{N}_{120} \mathrm{~S}_{40}$ in foreground and check in rear. Photographed in third year of study, May 16, 1961.

Table 2. Effects of fertilizer on percent ground cover-grazed plots.

\begin{tabular}{lccccccc}
\hline & \multicolumn{3}{c}{1961} & & \multicolumn{3}{c}{1962} \\
\cline { 2 - 7 } & $\begin{array}{c}\text { Cheat- } \\
\text { Trass }\end{array}$ & $\begin{array}{c}\text { Wheat- } \\
\text { grass }\end{array}$ & Total & $\begin{array}{c}\text { Cheat- } \\
\text { grass }\end{array}$ & $\begin{array}{c}\text { Wheat- } \\
\text { grass }\end{array}$ & Total \\
\hline None (check) & 1.9 & 3.3 & 5.2 & 17.3 & 18.3 & 36.3 \\
$\mathrm{~N}_{30}$ & 2.4 & 1.3 & 3.8 & 39.5 & 7.5 & 47.5 \\
$\mathrm{~N}_{60}$ & 1.2 & 0.6 & 1.9 & 53.5 & 1.0 & 55.0 \\
$\mathrm{~N}_{120}$ & 1.0 & 0.3 & 1.3 & 45.2 & 2.3 & 47.5 \\
$\mathrm{~S}_{40}$ & 1.4 & 4.1 & 5.6 & 9.3 & 26.8 & 36.3 \\
$\mathrm{~N}_{30} \mathrm{~S}_{40}$ & 2.0 & 2.2 & 4.2 & 38.3 & 10.0 & 50.0 \\
$\mathrm{~N}_{60} \mathrm{~S}_{40}$ & 1.7 & 0.9 & 2.6 & 51.0 & 2.5 & 55.0 \\
$\mathrm{~N}_{120} \mathrm{~S}_{40}$ & 0.7 & 0.1 & 0.9 & 40.0 & 2.5 & 46.0 \\
$\mathrm{AS}-300$ & 2.4 & 1.9 & 4.7 & 49.0 & 4.0 & 55.0 \\
LSD .05 & 0.7 & 1.6 & 2.2 & 14.3 & 5.7 & 11.5 \\
\multicolumn{1}{c}{.01} & 1.0 & 2.2 & 3.0 & 19.4 & 7.7 & 15.6 \\
\hline
\end{tabular}

${ }^{1}$ Rates of nitrogen $(\mathrm{N})$ and sulfur $(\mathrm{S})$ are given in $1 \mathrm{~b} / \mathrm{A}$. AS refers to ammonium sulfate and $\mathrm{lb} / \mathrm{A}$ of this material.

Wheatgrass recovered some in check plots in 1961 as the result of the better growing year of 1960 , but recovery was not as much as in the fenced plots (Table 2). Total ground cover of check plots was reduced sharply over the previous year, with cheatgrass reduction accounting for the decreases. Wheatgrass was almost completely killed out in the high-nutrient plots, the mortality being much higher than in the fenced plots $(0.1 \%$ ground cover on grazed plots compared to $1.5 \%$ on fenced plots, Figure 1).
Grazing by all classes of animals (wild and domestic) was heaviest where nitrogen fertilizers had been applied. The checks were also grazed harder than the general pasture because of their close proximity to the fertilized treatments. These factors may explain the differences in response between the fenced (mowed) experiment and the grazed experiment.

\section{Effects on Forage Production}

Forage yields varied more from year to year than they did between fertilizer applications (Table 3 ). The check varied from an estimated $25 \mathrm{lb} / \mathrm{A}$ in 1959 to $920 \mathrm{lb} / \mathrm{A}$ in 1962, a 36-fold difference which compares with only doubled yields by fertilizing even in the best year $(920 \mathrm{lb} / \mathrm{A}$ on check compared to $2290 \mathrm{lb} / \mathrm{A}$ on the $\mathrm{N}_{120} \mathrm{~S}_{40} \mathrm{R}$ ).

There was no increase in forage resulting from fertilization

\section{Table 3. Effects of fertilizer on oven-dry forage yields1.}

\begin{tabular}{lcr} 
& \multicolumn{2}{c}{ Yields - lb/A } \\
\cline { 2 - 3 } Treatment ${ }^{2}$ & 19603 & 1962 \\
\hline None (check) & 350 & 920 \\
$\mathrm{~N}_{30}$ & 360 & 1150 \\
$\mathrm{~N}_{30} \mathrm{R}$ & 410 & 1450 \\
$\mathrm{~N}_{60}$ & 430 & 1400 \\
$\mathrm{~N}_{60} \mathrm{R}$ & 400 & 1770 \\
$\mathrm{~N}_{120}$ & 390 & 1600 \\
$\mathrm{~N}_{120} \mathrm{R}$ & 420 & 1770 \\
$\mathrm{~S}_{40}$ & 290 & 1040 \\
$\mathrm{~N}_{30} \mathrm{~S}_{40}$ & 260 & 980 \\
$\mathrm{~N}_{30} \mathrm{~S}_{40} \mathrm{R}$ & 440 & 1800 \\
$\mathrm{~N}_{60} \mathrm{~S}_{40}$ & 360 & 1280 \\
$\mathrm{~N}_{60} \mathrm{~S}_{40} \mathrm{R}$ & 450 & 1820 \\
$\mathrm{~N}_{120} \mathrm{~S}_{40}$ & 410 & 1670 \\
$\mathrm{~N}_{120} \mathrm{~S}_{40} \mathrm{R}$ & 520 & 2290 \\
$\mathrm{AS}-300$ & - & 1200 \\
$\mathrm{AS}-300 \mathrm{R}$ & - & 2060 \\
$\mathrm{LSD} .05$ & 30 & 280 \\
\multicolumn{1}{c}{.01} & 40 & 390
\end{tabular}

1 Yields for 1959 were not taken, yield on check plots was estimated at $25 \mathrm{lb} / \mathrm{A}$; yields for 1961 averaged $35 \mathrm{lb} / \mathrm{A}$, no significant differences occurred among treatments.

2 Rates of nitrogen (N) and sulfur (S) are given in lb/A. $R$ refers to annual reapplication of nitrogen. AS refers to ammonium sulfate and $1 \mathrm{~b} / \mathrm{A}$ of this material.

3 Total of two clippings. 
in either of the two drier years, 1959 and 1961. Yields were increased significantly by many of the treatments in 1960 , but not enough to justify the expense of the fertilizer. Growth responses were much better in 1962 , a year when the extra feed produced by fertilization was not needed.

The single application of 60 $\mathrm{lb} / \mathrm{A}$ nitrogen at the beginning of the experiment continued to produce forage increases in the fourth growing season. The 30 $\mathrm{lb} / \mathrm{A}$ treatment failed to produce a yield response in any year unless repeated.

Table 4. Effects of fertilizer on protein contents (percent) of wheatgrass and cheatgrass; 1960 growing season.

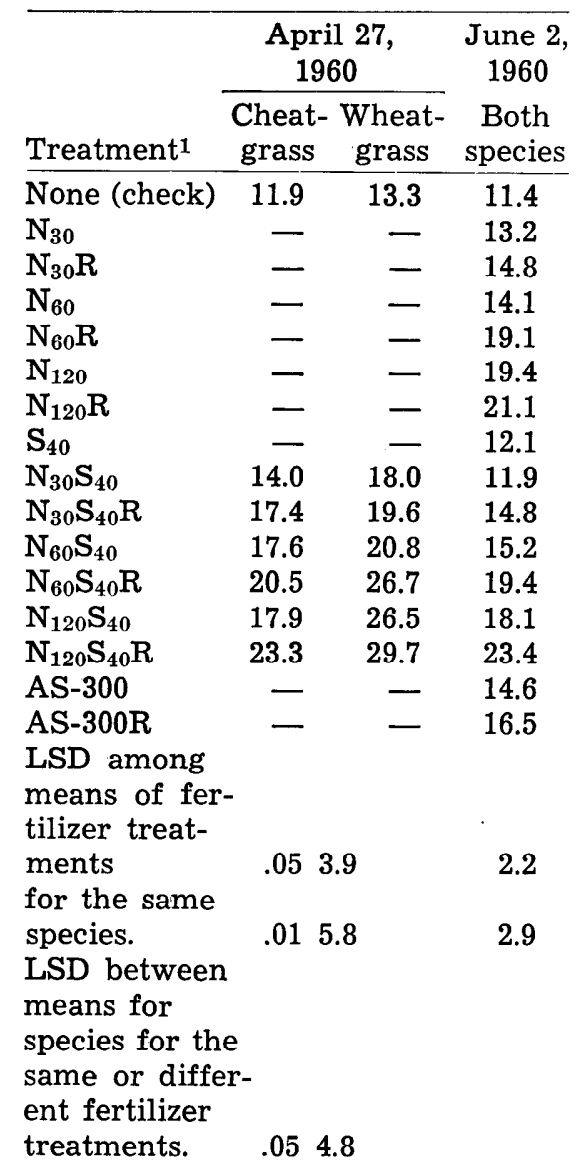

1 Rates of nitrogen (N) and sulfur (S) are given in lb/A. R refers to annual reapplication of nitrogen. AS refers to ammonium sulfate and $1 \mathrm{~b} / \mathrm{A}$ of this material.

\section{Supplementary Studies}

Forage quality. - The protein content of cheatgrass and wheatgrass were determined separately in the first clipping of 1960 and together in the second. The protein contents of both species generally were increased by nitrogen fertilization (Table 4). Wheatgrass was significantly higher in protein than was cheatgrass when both were heavily fertilized.

An analysis also was made for sulfate-sulfur. Again there was a significant difference between the species when heavily fertilized, wheatgrass being higher in sulfur $(0.464 \%)$ than was cheatgrass $(0.176 \%)$. Sulfur was also higher in the wheatgrass in the $\mathrm{N}_{120} \mathrm{~S}_{40}$ plot $(0.464 \%)$ than in the $\mathrm{N}_{120} \mathrm{~S}_{40} \mathrm{R}$ plot $(0.350 \%)$, indicating that the increased growth from repeated nitrogen applications had depleted the sulfur. This analysis also shows that sulfur carries over well in this soil and is not readily leached.

Soil moisture. - Soil moisture was measured gravimetrically at two depths-6-10 inches and 1216 inches-on May 17 and again on June 2, 1960. There were no differences in moisture attributable to fertilizer treatment on the first sampling date, but differences were apparent on the second date. Differences in use of moisture by cheatgrass and by wheatgrass were negligible. However, both species removed more moisture when fertilized than when not fertilized. Soil moisture on June 2, 1960 at 6-10 inches was $12.1 \%$ on the check and $9.4 \%$ on the $\mathrm{N}_{120} \mathrm{~S}_{40} \mathrm{R}$ plot. At the 12-16-inch depth moisture was $21.4 \%$ and $15.6 \%$, respectively.

Soil nitrogen.-Total soil nitrogen was measured at two depths (0-3 in. and 3-6 in.) at the end of the growing season in 1961 in the check, $\mathrm{N}_{120}$, and $\mathrm{N}_{120} \mathrm{R}$ plots to determine if nitrogen had ac- cumulated from the repeated applications. Total nitrogen in the soil samples averaged $0.085 \%$. No statistically significant differences were found. However the increases in yield the following year indicate that probably considerable nitrogen remained in the nitrogen plots.

Soil $p H$.- Soil $\mathrm{pH}$ was measured at two depths in the check and $\mathrm{N}_{120} \mathrm{~S}_{40} \mathrm{R}$ plots at the end of the third growing season to check on the possible effects of a lowered $\mathrm{pH}$ on the mortality of the wheatgrass. The $\mathrm{pH}$ in the treated plots was significantly reduced at both depths, but not sufficiently to contribute to the mortality. At the 0-3 inch depth, $\mathrm{pH}$ was 7.2 on the checks and 6.9 on the $\mathrm{N}_{120} \mathrm{~S}_{40} \mathrm{R}$ plots; at the 3-6 inch depth it was 7.4 and 7.0 respectively.

\section{Conclusion}

Results of the 4-year fertilization study on cheatgrass and intermediate wheatgrass indicate that applied nitrogen, especially at the higher rates, favored cheatgrass at the expense of wheatgrass. Grazing increased the detrimental effects of high nitrogen fertilization on intermediate wheatgrass.

Increased growth of cheatgrass with high nitrogen, coupled with extremely dry years, is concluded to be the principal cause of the marked reduction of intermediate wheatgrass.

Under the soil and moisture conditions of this experiment, fertilization of intermediate wheatgrass and cheatgrass is not economical, and also may cause serious damage to the wheatgrass.

\section{Summary}

A 4-year fertilizer study was established on a 1-year old stand of intermediate wheatgrass infested with cheatgrass. Two field trials were included, one open to grazing and the other protected. Nitrogen was applied at three 
rates, with and without sulfur. Initial application of nitrogen was compared with annual reapplication. Plots were sampled for yield and botanical composition by ground cover.

Results indicated that applied nitrogen, especially at the higher rates, favored cheatgrass at the expense of the wheatgrass under the dry conditions of this study. Grazing increased the detrimental effects of high nitrogen fertilization on intermediate wheatgrass. Rapid depletion of soilmoisture, the result of increased growth of cheatgrass under high nitrogen in a period of belownormal precipitation, was postulated to be the principal cause of reduction of intermediate wheatgrass.
Increases in forage yield occurred only in the better forage years. In the poorer years no forage increase resulted from fertilization. In no instance did the forage response justify the cost of the fertilizer.

\section{LITERATURE CITED}

ECKERT, Richard E., A. T. BLEAK, AND Jos. H. ROBERTSON. 1961. Effects of macro- and micronutrients on the yield of crested wheatgrass. Jour. Range Mangt. 14: 149-155.

EcKert, RichaRd E., AND Raymond A. Evans. 1963. Responses of downy brome (Bromus tectorum) and crested wheatgrass (Agropyron desertorum) to nitrogen and phosphorus in nutrient solution. Weeds 11: $170-174$.

Evans, R. A., ANd R. M. Love. 1957. The step-point method of sampling - a practical tool in range research. Jour. Range Mangt. 10: 208-212.

HowaRD, W. E., AND B. L. KAY. 1957. Protecting range forage plots from rodents. Jour. Range Mangt. 10: 178-180.

KAY, Burgess L., C. F. WALKer, J. E. Street AND J. L. MYler. 1958. Range demonstration 1958 - progress report - University of California, Davis.

Kay, Burgess L., J. E. Street and C. W. RIMBEY. 1957. Nitrogen carryover on range. Cal. Agr. 11(10): 5 \& 10.

KILCHER, MARK R. 1958. Fertilizer effects on hay production of three cultivated grasses in Southern Saskatchewan. Jour. Range Mangt. 11: 231-234.

Sneva, Forrest A., Donald N. Hyder, AND C. S. Cooper. 1958. The influence of ammonium nitrate on the growth and yield of crested wheatgrass on the Oregon high desert. Agron. Jour. 50: 40-44. 